AROVINA MARYNA,

Candidate of Science in Public Administration, Associate Professor, Donetsk National University named after Vasyl Stus, Vinnitsa

\title{
FORMATION OF THE ECOSYSTEM OF OPEN DATA IN UKRAINE AS A FACTOR OF THE DEVELOPMENT OF THE REGIONAL ECONOMY
}

The article is devoted to the research of the information service of open data in the context of influence on the development of the regional economy. The concepts of "ecosystem", "open data", their essence and significance as endogenous and exogenous factors are considered. The state of development of separate elements of the open data ecosystem formed in Ukraine is characterized. The foreign experience of organizing such information resources has been analyzed. The main problems are identified, such as weak integration of regional information resources into a single open data system, insufficient use of the potential of domestic IT professionals. The directions of improving the ecosystem of the open data of Ukraine are proposed.

Key words: ecosystem; open data; regional economy; data managers; endogenous and exogenous factors; data sets; institutional readiness; economic benefits; cloud technologies.

Formulation of the problem. Currently Ukraine implements a series of ambitious reforms designed to unite the efforts of the government and civil society in the direction of global informatization. This is facilitated by the development of the information space of the country, the formation of electronic government. Among the key tools for improving the mechanism of regional power, new information technologies should be noted that allow the use of public information in the form of public data.

In accordance with the "State Strategy for Regional Development for the period to 2020", two main groups of factors affecting the state of the regional economy are distinguished: exogenous (external) and endogenous (internal). Exogenous factors include the openness of the economy, the correctness and timeliness of decisionmaking by the authorities. Endogenous are formed as a result of the internal features of the region, its historical development, geographical, political, economic, demoethnic, sociocultural and other factors, as well as peculiarities of the formation of the institutional environment for development [1]. Open data are extensive and varied, and can act both as exogenous and as endogenous factors, which evidenced by the provisions of the Law of Ukraine "On Access to Public Information", the Decree of the Cabinet of Ministers of Ukraine "On approval of the Regulations on data sets to be published in the form Open data" [2, 3].

In developed foreign countries (USA, Great Britain, etc.), the organization of open data is carried out on the basis of the ecosystem principle. For Ukraine, this approach is new, the domestic scientific base is in the process of formation. In this sense, the theme of the work is relevant, both theoretically and in practice.

Analysis of recent research and publications. The economic aspects of the use of open data in foreign countries attract close attention, both individual scientists and research organizations, whose research interests are concentrated directly in the above area (for example, the Open Data Institute, London) [4]. Today in the world science there is no doubt the hypothesis that information transformed into accumulated knowledge is a source of competitive advantage. According to the experts of the Warsaw Institute of Economic Research (Warszawski Instytut Studiyw Ekonomicznych) open public data are a resource that serves development and innovation [5]. In Ukraine, the work of the specialists of the State Agency for Electronic Government of Ukraine [6, 7], reports of public organizations [8-10], articles of experts in the field of IT technologies are devoted to the critical analysis of the organization of the open data Internet service [11].

The purpose of the article is to substantiate the organization of open data resources in the form of an ecosystem as a factor in the development of the regional economy.

Objectives of the study:

- characterize the concepts: "open data", "ecosystem", their significance in the development of the regional economy;

- analyze the elements of the open data ecosystem in Ukraine, identify the main problems;

- identify areas for improving the ecosystem of open data in the context of the impact on the development of the regional economy.

Statement of the main material. According to the current legislation of Ukraine, public data is public information in a format that allows its automated processing by electronic means, free and free access to it of individuals and legal entities, as well as its further use [2, art. 10]. Legislatively fixed the basic principles of the creation and use of this information (Fig. 1).

As users can act any person who needs information, which has the status of open. The supervisors are entities that have the rights and obligations to publish public information that is in their possession (Table 1).

The concept of "ecosystem" is relatively new for domestic management science. It was first introduced and developed in biology (1935, Arthur Tansley). The scientist 


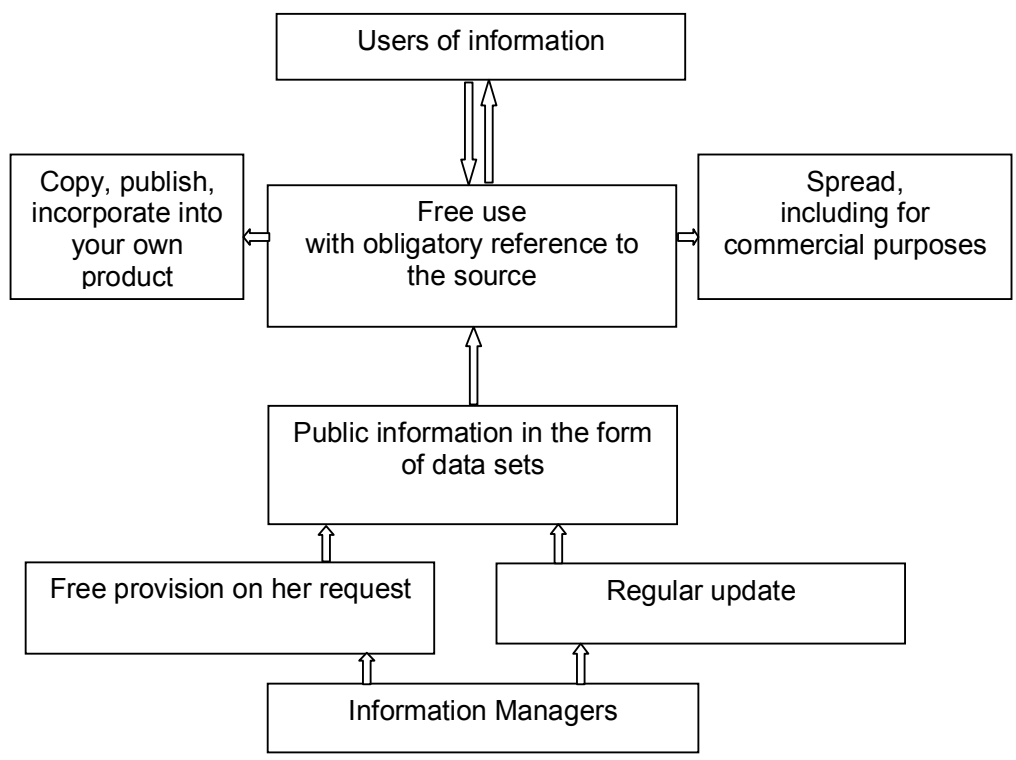

Fig. 1. Principles of creating and using public data [2].

Table 1. - The main groups of information managers [2, page 13]

\begin{tabular}{|l|l|}
\hline \multicolumn{1}{|c|}{ Information Managers } & \multicolumn{1}{|c|}{ Types of published information } \\
\hline $\begin{array}{l}\text { Bodies of state power, local self-government, other entities exercising } \\
\text { power management functions }\end{array}$ & Mandatory decisions \\
\hline Legal entities that are financed from the state, local budgets & Use of budgetary funds \\
\hline Persons performing delegated powers of subjects of power & Information on the performance of duties \\
\hline $\begin{array}{l}\text { Business entities that occupy a dominant position in the market or are } \\
\text { endowed with special rights }\end{array}$ & $\begin{array}{l}\text { Terms of delivery of goods, services and } \\
\text { prices for them }\end{array}$ \\
\hline
\end{tabular}

has proved that the totality of organisms living in a particular biotope is a system, with certain elements, a single history and the ability for coordinated development [12].

At the end of the twentieth century, James F. Moore (James F. Moore) substantiated the use of the term "ecosystem" in the field of management (the theory of entrepreneurial systems). The ecosystem concept, on the one hand, translates the general laws of organization of systems into the business sphere, such as self-preservation, synergy, development, the whole over the part, the system of needs, need for management. On the other hand, the transfer of specific aspects of natural ecosystems. The idea is that every element in the "ecosystem" (producers, consumers, government agencies, etc.) influences and depends on other bases of competition and cooperation, creating an ever-developing relationship. In them, business must be flexible and adapt to survive, as in a biological ecosystem [14].

Based on the principles of the ecosystem, a global Internet network has been established and is functioning. The emergence of any newly created information resource in the global space implies joint participation, development based on open standards and free access to the processes that determine technology and strategy. This concept for open data is accepted and implemented in practice by the European Data Portal, the USA (Data.Gov), and other developed countries of the world $[15,16]$.

The open data ecosystem (World Bank) includes the following elements:

- forms of data provision;

- regulatory framework of activities;

- institutional readiness;

- the capacity to provide information;

- participation of citizens in the process of public administration;
- financing of innovation;

- availability of technological infrastructure [17].

Analyze the presence of the above elements in the open data system of Ukraine. As mentioned above, the domestic regulatory framework for the provision of open data is generally formed [2, 3]. In addition, in 2016 our country joined the International Charter of Open Data within the framework of the Open Government Partnership (OGP) Internet project. In order to become a member of the OGP, countries must endorse the Open Government Declaration, develop an action plan based on public consultation, and report on progress achieved [17]. It should be noted that the term "ecosystem" does not exist in the normative acts of Ukraine on open data, but is used in various analytical materials.

Internet-service of open data in Ukraine from 2015 is the Unified State Portal of Open Data. The information that is published on it exists in the form of data sets - electronic documents representing a structured set of homogeneous values (records) $[3,18]$. The sets are grouped into separate spheres (Table 2).

The data of Table 2 indicate that the public sector (the third part of all data), the financial and tax spheres (16.4 and $12.5 \%$, respectively) are most widely represented in the structure of open data. The problems of standardization, youth and sports, ecology, transport, construction, agriculture, land tenure (the tenth part in the aggregate) are the least covered.

The analysis of foreign studies indicates that the predominance of the share of state data in the overall structure is one of the most important factors in the development of entrepreneurship. So, according to the Open Data Institute survey, $70 \%$ of UK companies use open public data sets, non-state information resources - $49 \%$. At the same time, 
Table 2. - Ranking of open data from a single state portal [18]

\begin{tabular}{|l|c|c|}
\hline \multicolumn{1}{|c|}{ Sphere of activity } & $\begin{array}{c}\text { Number } \\
\text { of datasets }\end{array}$ & $\begin{array}{c}\% \text { of the } \\
\text { total number } \\
\text { of sets }\end{array}$ \\
\hline 1. The state & 3123 & 32,0 \\
\hline 2. Taxes & 1605 & 16,4 \\
\hline 3. Finance & 1219 & 12,5 \\
\hline 4. Social protection & 759 & 7,8 \\
\hline 5. Health protection & 690 & 7,1 \\
\hline 6. Justice & 644 & 6,6 \\
\hline 7. Education and culture & 438 & 4,5 \\
\hline 8. Economy & 327 & 3,3 \\
\hline 9. Earth & 200 & 2,0 \\
\hline 10. Agriculture & 190 & 1,9 \\
\hline 11. Building & 181 & 1,9 \\
\hline 12. Transport & 123 & 1,3 \\
\hline 13. Ecology & 111 & 1,1 \\
\hline 14. Youth and Sports & 89 & 0,9 \\
\hline 15. Standards & 70 & 0,7 \\
\hline Total & 9769 & 100,0 \\
\hline
\end{tabular}

among the non-state, the most popular among businessmen are logistic data [4].

Institutional readiness and potential in world practice are assessed on the basis of the following methods [9]:

- Open Data Readiness Assessment (World Bank) readiness of the central government, regional and municipal authorities and individual agencies to develop and implement the initiative to open and use government data;

- Open Data Barometer (World Wide Web Foundation), the progress of each country in three categories (the wil- lingness of the government, society and business to open data, the implementation of laws on open data, the political, economic and social impact of the discovery of government data), the availability and quality of key sets Data in 15 categories.

A comparative analysis of the readiness of Ukraine, the United States and Great Britain on the methodology of the World Wide Web Foundation is shown in Fig.

The data in Fig. 2 show that the state and business structures of Ukraine show some activity in providing open data, but the impact on the economy is still very small, in contrast to the United States and Great Britain, where the relevant criteria are maximum (87-100).

Studies have shown that the number of sets of open data is an important, but not a priority, factor in the development of the economy. Thus, the number of sets of open data in Ukraine is several times higher than in Poland and Finland. However, the impact of open data on the economy in these countries is much higher than in our country. The highest economic impact (100) is demonstrated by the United Kingdom, while the United States is the world leader in the number of sets of open data. Note that in Poland, where the start time of the open data platform formation is comparable to Ukraine (2014), the impact on the economy is 6 times higher (Table 3 ).

It is logical to assume that a greater or lesser degree of interest in the development of the regional structure of open data portals is directly dependent on state regional policy. It provides the equilibrium effect of exogenous and endogenous information factors on the development of the regional economy. Thus, $71 \%$ of the EU countries have regional or local portals, except for the national one. The

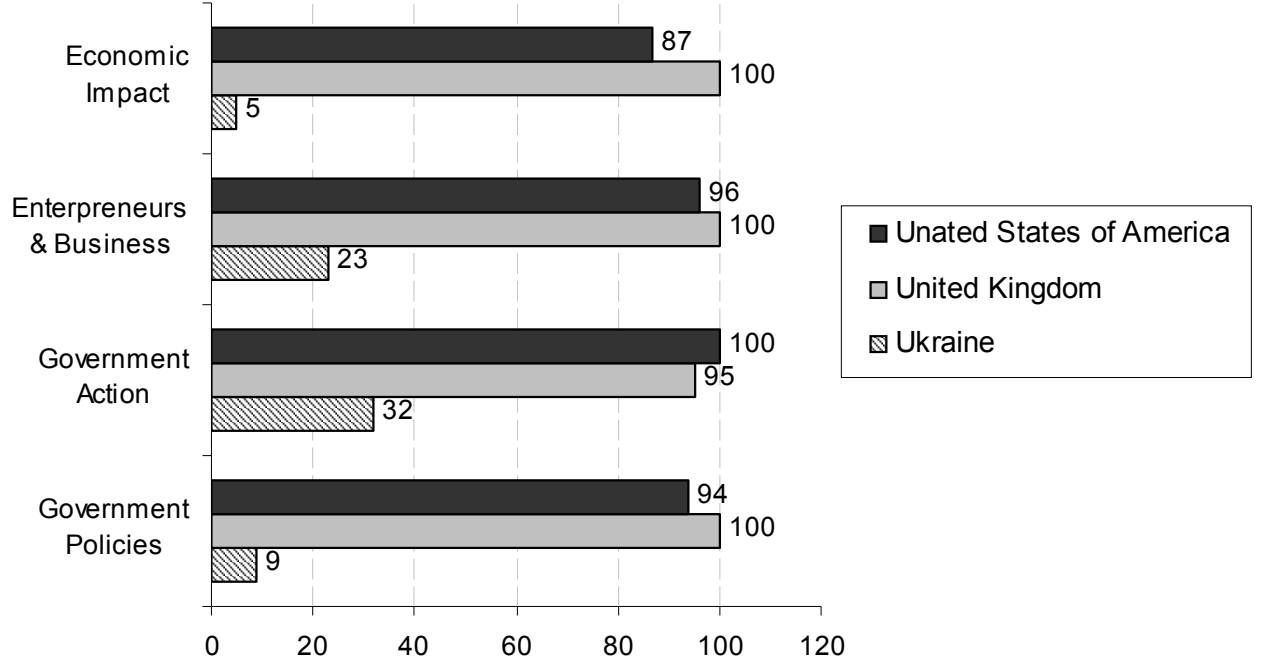

Fig. 2. Comparative analysis of readiness to open data of the USA, Great Britain, Ukraine [19].

Table 3. - Number of sets of open data in some countries of the world (January 2017) [19]

\begin{tabular}{|l|l|c|c|}
\hline \multicolumn{1}{|c|}{ A country } & \multicolumn{1}{|c|}{ Open Data Portal } & $\begin{array}{c}\text { Number of sets } \\
\text { of open data }\end{array}$ & $\begin{array}{c}\text { Economic } \\
\text { Impact }\end{array}$ \\
\hline USA & https://www.data.gov & 166945 & 87 \\
\hline United Kingdom & https://data.gov.uk/data/search & 42151 & 100 \\
\hline Germany & https://www.govdata.de/web/guest/daten & 189389 & 34 \\
\hline Japan & http://www.data.go.jp/data/en/dataset & 17861 & 49 \\
\hline Ukraine & http://data.gov.ua & 9769 & 5 \\
\hline Finland & $\begin{array}{l}\text { http://www.hri.fi/fi/dataset?q=\&sort=metadata_created+ } \\
\text { desc }\end{array}$ & 2621 & 54 \\
\hline Austria & http://data.opendataportal.at/dataset & 4006 & 47 \\
\hline Poland & https://danepubliczne.gov.pl/dataset & 827 & 31 \\
\hline
\end{tabular}


higher the degrees of coordination, the more regional portals are integrated into national ones. For example, in Germany the issue is partially resolved, in Austria - by $100 \%$. The open data portal in the USA possesses the developed regional structure $[15,16]$.

In Ukraine, the regional component of open data is still very poorly developed. The information resources that are focused on the Unified State Portal are not structured around the regions, which make it difficult to find the necessary information for local legal entities and individuals. Lack of information also manifests itself in the absence of open data on more than half of the operating municipal sites of large cities (Fig. 3).

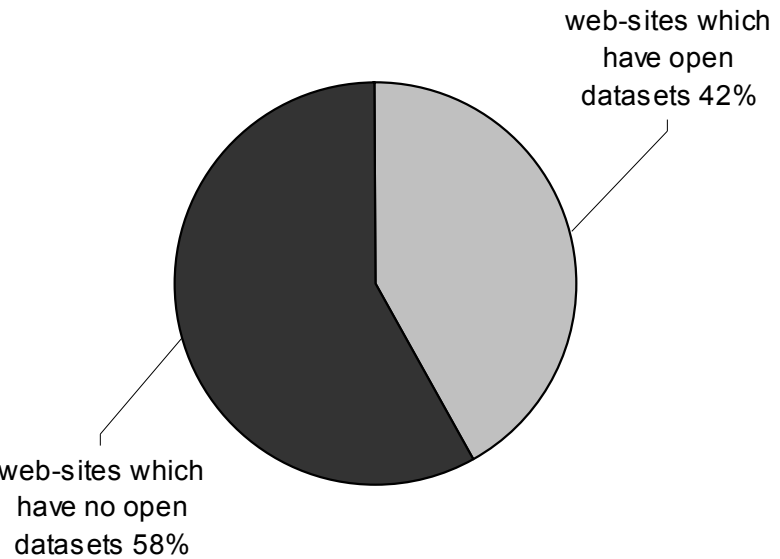

Fig. 3. Urban web-sites that have open data sets [10].

Given the uneven development of the regions, a significant differentiation in the development of regions and cities, of which (for more than $30 \%$ ) for a long time there is a simultaneous decrease in the level of economic activity and a decrease in population, open data can become an innovative tool for regional development [1].

According to experts, the functioning of information resources of open data in the form of an ecosystem contributes to improving the business climate, transparency of interaction between business and the state [6]. Understanding of these processes by the state ensures the progressive economic development of the countries of the Eurozone. The experts of the EGAP (e-Government for accountability and participation) program evaluated the growth of the volume of open data in the countries of the European Union, predicted economic benefits by developing various sectors of the economy, creating new jobs (Table 4).

Significant growth in economic indicators, presented in Table 4, in the countries of the Eurozone is expected to be achieved by expanding the open data market. Consequently, such perspectives exist in Ukraine, provided that the Internet public information services are optimally organized.

As for the interaction of the state and society in the context of the formation of Ukraine's open data platform, we note a number of positive points. So, the functioning of the Unified State Portal of Open Data is provided not only by state bodies (the State Agency for Electronic Government of Ukraine, the Cabinet of Ministers of Ukraine, etc.), but also by public organizations (SocialBoost, International Renaissance Foundation, etc.), which monitor activities. In addition, the experience of using the work of IT volunteers in the creation of the Public Service Portal iGOV has been accumulated [20].

Considering the issue of financing innovation, we will outline the main factors that correspond to the concept of the ecosystem [5]:

- the experience of involving developers in the creation of software applications and electronic services from various departments;

- joint activities to create software applications and electronic services, such as computer software competitions, software application developers, and so on;

- the presence of a critical mass of local developers, and they, as a community, actively participate in social media platforms and privately;

- availability of financing at the initial stage for entrepreneurs and newly established companies.

Studies have shown that the pace of formation of this element of the ecosystem is low, and the regional component develops selectively. Thus, within the framework of the National IT Projects Competition EGAP Challenge (2016-2017), which involves the participation of startups based on open data, the planned number of winners nationwide is - 12. The contest involves four regions of Ukraine: Vinnitsa, Volyn, Dneprovskaya and Odessa Region [21]. During the period of the "1991 Open Data Incubator" project (since 2012) 20 projects have been funded [22].

At the same time, the potential for the development of the IT sphere in Ukraine is very high. According to PwC Ukraine, from 2011 to 2015 , the number of IT professionals increased from 42.4 to 91.7 thousand people, and the contribution of the IT sector to the country's GDP increased from 1.1 to 2.7 billion dollars [23]. It is obvious that the domestic IT-base can be used more effectively. The progress in the formation of the ecosystem will depend on the efforts of the state to attract local personnel to the process of processing open data.

The basis of the technological infrastructure of the portal of open data in Ukraine (http://data.gov.ua) is the use of "cloud models" that allow not only to store large amounts of data, but also to create various applications, expand the scale of providing information, while ensuring

Table 4. - Forecast of economic benefits of the countries of the Eurozone from the use of open data in the period 2016-2020 [6]

\begin{tabular}{|c|c|c|}
\hline Index & 2016 year & 2020 year \\
\hline The volume of the direct market of open data (direct market size) billion euros & 55,3 & 75,7 \\
\hline The total market value of open data in $€$ billion & 193-209 & $265-286$ \\
\hline $\begin{array}{l}\text { Benefits from the development of open data: } \\
\text { public sector } € \text { billion }\end{array}$ & - & 22 \\
\hline agriculture $€$ billion & - & 0,379 \\
\hline art $€$ billion & - & 0,379 \\
\hline entertainment sector $€$ billion & - & 0,379 \\
\hline Total number of jobs associated with the use of open data, people. & 75000 & 100000 \\
\hline
\end{tabular}

\section{СХІД № 1 (147) січень-лютий 2017 p.}


a high level Protection. The information system supports various computer-readable data formats: text, graphic, audio, video, archive, etc. The request for public data is carried out through the user's personal cabinet [18]. In online mode, users can search for data sets with different criteria: keywords, information managers, etc.; managers - implement monitoring of views and downloads of data sets [24]. The above technological aspects of the interaction of the managers of data sets and users in general correspond to the principles of the ecosystem. A further step in its improvement should be cooperation in the organization of regional platforms for open data and their integration into a single information resource.

Thus, based on the studies carried out, the following conclusions can be drawn.

1. Concepts: "open data", "ecosystem" are new for the domestic science, but their importance in the development of the regional economy in the era of universal informatization is constantly increasing.

2. The formation of separate elements of the ecosystem of open data in Ukraine is uneven. Among the most developed are the regulatory legal and technological components. A significant number of sets of open data do not ensure the needs of economic entities in full, as evidenced by the Open Data Barometer. The regional structure of open data is not developed enough; the potential of domestic IT specialists is poorly used.

3 . The main directions of improving the ecosystem of open data in the context of the impact on the development of the regional economy is the organization of relevant services on the websites of municipal authorities, their integration into the system of the Unified State Portal of Open Data.

\section{REFERENCES}

1. National Strategy for Regional Development until 2020. Approved by the Cabinet of Ministers of 6 August 2014. № 385, available at: http://zakon2.rada.gov.ua/laws/show/385-2014-ח

2. Law of Ukraine «On Access to Public Information» (Supreme Council of Ukraine (VVR), 2011, № 32, Article 10, 13, 31, available at: http: //zakon0.rada. gov.ua/laws/show/2939-17

3. The Cabinet of Ministers of Ukraine on October 21, 2015 № 835 «On Approval of the datasets to be published in the form of open data», available at: http://zakon3.rada.gov.ua/ laws / show / 835-2015-p

4. Open Data Institute, London, available at: http://theodi.org.

5. Buchholtz, Sonia \& Strycharz, Jan \& Њniegocki Aleksander \& Tarkovsky Alek (2015), Market products, services and digital content based on the re-use of public sector information (PSI) in Poland: current situation, prospects, significant barriers recommendations for support from the European funds, Final Report. Warsaw Institute of Economic Studies, available at: http://
www.polskacyfrowa.gov.pl/media/1076/POPC_WISECC_ISP_ raportkoncowy_2112015.pdf

6. How open data stimulate the economy of the EU or the Eurozone experience to unleash the potential of open data in Ukraine, available at: http://www.dknii.gov.ua/content/yak-vidkrytidani-stymulyuyut-rozvytok-ekonomiky-yes-abo-dosvidyevrozony-dlya-rozkryttya

7. Evaluation of Ukraine's readiness to implement open data, available at: http://dhrp.org.ua/uk/publikatsii1/1071-20160227-uapublication

8. Lukyanov, Olexander (2015), Openness data as a prerequisite for the formation of civil society in Ukraine, without corruption, available at: http://gurt.org.ua/articles/28385/bull/

9. Gazin, A. (2016), Open data ecosystem in Ukraine: Recommendations for implementing policy, available at: http:// www.irf.ua/knowledgebase/publications/ekosistema_vidkritikh _danikh_v_ukraini_rekomendatsii_schodo_vprovadzhennya_politiki/

10. These cities Ukraine: Open data in progress, available at: https://danimist.org.ua/doslidzhennya2.html

11. Handzyuk, K. (2015), Open data, available at: http:// most.ks.ua/news/url/vidkriti_dani_angl_open_data

12. Arthur Tansley. Article from Wikipedia, available at: https:/ /uk.wikipedia.org/wiki/Артур_Тенслі

13. Moore, James (1993), Predators and Prey: A new ecology of competition, Harvard Business Review. 71 (3; May-June), available at: https://www.ncbi.nlm.nih.gov/pubmed/10126156

14. Vusiness Ekosystem, available at: http://www.investopedia.com/terms/b/business-ecosystem.asp

15. European Data Portal, available at: https:// www.europeandataportal.eu/en/using-data

16. Data.Gov, available at: https://catalog.data.gov/dataset

17. Some questions joining the International Charter of open data. CMU on September 22, 2016 №686-p, available at: http:// www.kmu.gov.ua/control/uk/cardnpd ?docid $=249350048$

18. The only state open data portal, available at: http:// data.gov.ua

19. Open data barometer, available at: http:// opendatabarometer.org/data-explorer/?_year=2015\&indicator $=\mathrm{ODB} \&$ open $=U K R \&$ compare $\mathrm{w}=\mathrm{GBR}$

20. Public Services Portal, available at: https://igov.org.ua

21. Ukraine's first competition of IT projects on e-democracy, available at: http://egap-challenge.in.ua

22. The 1991 Open Data Incubator, available at: http://1991.vc/

23. Andrienko-Bentz, O. (2016), Export-oriented segment of Ukraine's IT services market: Status quo and prospects PwC Ukraine, available at: http://www.eba.com.ua/static/export_it_ industryfinal_29092016.pdf

24. The Cabinet of Ministers of Ukraine of 30 November 2016 № 867 «Some questions of disclosure of public information in the form of open data», available at: http://www.kmu.gov.ua/control/ uk/cardnpd?docid $=249551462$

Аровина Марина,

кандидат наук по государственному управлению, доцент,

Донеикий национальный университет имени Василия Стуса, г. Винница

\section{ФОРМИРОВАНИЕ ЭКОСИСТЕМЫ ОТКРЫТЫХ ДАННЫХ В УКРАИНЕ КАК ФАКТОРА РАЗВИТИЯ РЕГИОНАЛЬНОЙ ЭКОНОМИКИ}

Статья посвящена исследованию информационного сервиса открытых данных в контексте влияния на развитие региональной экономики. Рассмотрены понятия "экосистема", "открытые данные", их сущность и значение как эндогенных и экзогенных факторов. Охарактеризовано состояние развития отдельных элементов формирующейся в Украине экосистемы открытых данных. Проанализирован зарубежный опыт организации подобных информационных ресурсов. 
Выявлены основные проблемы, такие как слабая интегрированность региональных информационных ресурсов в единую систему открытых данных, недостаточное использование потенциала отечественных ИТспециалистов.

Предложены направления совершенствования экосистемы открытых данных Украины.

Ключевые слова: экосистема; открытые данные; региональная экономика; распорядители данных; эндогенные и экзогенные факторы; наборы данных; институциональная готовность; экономическая выгода; облачные технологии.

Аровіна Марина,

кандидат наук з державного управління, доиент,

Донецький національний університет імені Василя Стуса, м. Вінниия

\section{ФОРМУВАННЯ ЕКОСИСТЕМИ ВІДКРИТИХ ДАНИХ В УКРӒ̈НІ ЯК ФАКТОРА РОЗВИТКУ РЕГІОНАЛЬНОÏ ЕКОНОМІКИ}

У статті досліджено особливості формування екосистеми відкритих даних в контексті впливу на розвиток регіональної економіки. Охарактеризовано поняття "відкриті дані", закріплене чинним законодавством України. Розглянуто принципи організації Інтернет-платформи відкритих даних, наведено класифікацію розпорядників інформації, види публічної інформації.

Розглянуто трансформацію терміна "екосистема" при перенесенні специфічних аспектів природних екосистем на сферу підприємництва. Підкреслюється ідея про взаємозалежність, взаємовплив, гнучкість та адаптивність елементів в "екосистемі" бізнесу в процесі виживання. Наведені приклади застосування концепції екосистем в інформаційній сфері - глобальна мережа Інтернет, портали відкритих даних розвинених країн світу.

Проведено аналіз формування елементів екосистеми відкритих даних в Україні. Встановлено, що в числі найбільш розвинутих елементів - нормативно-правова база діяльності, наявність потенціалу в наданні інформації, якісна технологічна інфраструктура. Дослідження показали, що до тепер на єдиному державному порталі відкритих даних опубліковано значну кількість наборів даних, при цьому найбільш широко представлений державний сектор, що відповідає світовим тенденціям попиту споживачів інформації.

Показано, що інституційна готовність країни до відкриття даних, яка визначається за методикою World Wide Web Foundation, $є$ низькою, вплив на економіку поки що незначний у порівнянні з країнами-лідерами, такими як США і Великобританія.

Відзначено, що в розвинених країнах регіональні відкриті дані інтегровані в центральні портали, що значно полегшує пошук інформації і роботу споживачів 3 нею. Встановлено, що в Україні більше половини муніципальних сайтів великих міст не мають ресурсів відкритих даних. Виявлено проблеми фінансування інновацій в ITсфері, при наявності істотного потенціалу вітчизняних фахівців.

Запропоновано напрями вдосконалення екосистеми відкритих даних України, пов'язані зі структуруванням інформації в регіональному контексті, з одного боку, інтегрування регіональних інформаційних ресурсів в центральний портал, 3 іншого, а також широке залучення вітчизняних фахівців в організацію стартапів на основі використання відкритих даних.

Ключові слова: екосистема; відкриті дані; регіональна економіка; розпорядники даних; ендогенні і екзогенні чинники; набори даних; інституційна готовність; економічна вигода; хмарні технології.

(C) Аровіна Марина

Надійшла до редакції 18.01.2017 